\title{
POLLEN MORPHOLOGY IN SELECTED CUPRESSACEAE GRAY. AND SCIADOPITYACEAE LUERSS. SPECIES IN AN EXPERIMENTAL CULTURE
}

\author{
Joanna Bykowska, MaŁgorzata Klimko
}

\begin{abstract}
J. Bykowska, Department of Dendrology and Nursery, Poznań University of Life Sciences, Baranowo, Szamotulska 28, 62-081 Przeźmierowo, Poland, e-mail: jozal@up.poznan.pl

M. Klimko, Department of Botany, Poznań University of Life Sciences, Wojska Polskiego 71 C, 60-625

Poznań, Poland, e-mail: klim@up.poznan.pl
\end{abstract}

(Received: August 12, 2015. Accepted: December 2, 2015)

\begin{abstract}
Pollen grains of Cunninghamia lanceolata, Cryptomeria japonica and Sciadopitys verticillata were examined by light and scanning electron microscopy. The pollen grains were non-saccate, generally oblate-spheroidal, spheroidal, prolate-spheroidal or subprolate. The pollen grains had papillae of different sizes and shapes on the distal face. The papillae were more conspicuous in C. japonica than in C. lanceolata. The pollen exine sculpture in the proximal view was verrucate-granulate and verrcucate with microechinate suprasculpture in SEM. The surface of the exine was covered with echinate orbicules in Cupressaceae species. There were some differences in the size of the verrucae, perforation on the proximal surface and distal face between $S$. verticillata pollen grains and other species. This study of the pollen grain morphology provided some important new data which have not been reported in literature so far.
\end{abstract}

KeY WORDS: Cunninghamia lanceolata, Cryptomeria japonica, Sciadopitys verticillata, pollen morphology, LM, SEM

\section{INTRODUCTION}

Cunninghamia lanceolata Hook., Cryptomeria japonica D. Don and Sciadopitys verticillata Sieb. et Zucc. are original gymnospermous trees of the Taxodiaceae family. Over the past decades scientists postulated the dissimilarity of Sciadopitys verticillata. As a result, from time to time the species was classified as a different family, i.e. Sciadopityaceae (HAYATA 1931, Xi 1986, Schulz \& Stützel 2007, Christenhusz et al. 2011, Uehara \& Saiki 2011). However, species of the Taxodiaceae family are sometimes classified as the Cupressaceae family due to the characteristic features of their cones and due to the findings of some molecular and morphological phylogenetic studies (Seneta \& Dolatowski 2000, Schulz \& Stützel 2007, Christenhusz et al. 2011).

Cunninghamia lanceolata, Cryptomeria japonica and Sciadopitys verticillata are native Asian species. There are natural habitats of $C$. lanceolata in central and southern China. S. verticillata has its natural habitat only in the Japanese mountains on the islands of Honshu, Shikoku and Kyushu (Seneta 1981, Grímsson \& ZetTer 2011). Cryptomeria japonica can naturally be found in Japan, but its botanic variety (var. sinensis) can also be found in China (Seneta 1981, Uehara \& SAHASHI 2000). Conspicuous, old C. japonica trees grow near Japanese temples and palaces in impressive alleys (SENETA 1981). Thanks to its decorative values the species has often been planted as an ornamental tree. Due to its rapid growth and valuable wood it is still one of the most important forest trees in Japan (SENEta 1981, Page 1990, Uehara \& Sahashi 2000). Forests with C. japonica occupy nearly $18 \%$ of the total land area of Japan (YoneKuRA et al. 2012). Due to the large number of trees with light pollen, which can be carried by wind even as far as several dozen kilometres, nowadays the $C$. japonica pollen is an onerous allergen in spring (TANAKA et al. 2012, WANG et al. 2012, 2013).

Cunninghamia lanceolata, C. japonica and S. verticillata were introduced to Poland in the $19^{\text {th }}$ century. However, due to their limited resistance to frost and poor commercial availability the species can only be found as collectors' specimens in Poland. Nevertheless, in Austria (Zetter 1998, Grímsson \& Zetter 2011), Denmark (Larsson et al. 2010), Germany (Ferguson et al. 1998) and Poland (MАс́ко 1957, SтUchlik et al. 2002, Troć \& Sadowska 2006) S. verticillata pollen 
grains were noted in Miocene fossil specimens. Similarly, specimens of $C$. lanceolata pollen grains were found in Austria (Grímsson \& ZETTer 2011).

Pollen grains are surrounded by complex pollen walls with the outer granular layer (ectexine) and the inner lamellar layer (endexine) (Uehara \& SAHASHI 2000). In the Taxodiaceae family pollen grains are generally spherical and granular (UEHARA \& SAHASHI 2000), non-saccate (KuRMANN 1990, UeHARA \& SAHASH 2000), frequently with a papilla in the middle of the leptoma (Grímsson \& ZetTer 2011). Several authors have reported on the morphology and ultrastructure of C. lanceolata pollen grains (XI 1986, Surova \& Kvavadze 1988, XI \& Wang 1989, KurmanN 1990 and JiA et al. 1998); C. japonica - by Ueno (1951, 1960), YAMAdA et al. (1980), XI \& WANG (1989), KuRMANN (1992), Uehara \& SAHASHI (2000) and S. verticillata - by Kvavadze (1986) and Hansen et al. (2001).

The main aims of this study were to: 1 . describe variation in the pollen grain morphology of $C$. lanceolata, C. japonica and S. verticillata; 2 . describe and document the pollen grain micromorphology; 3 . supply new data, which can be used for identification of the species under study.

\section{MATERIAL AND METHODS}

In March and April 2015 Cunninghamia lanceolata, Cryptomeria japonica and Sciadopitys verticillata pollen grains were collected from trees growing in the collection of the Department of Dendrology and Nursery, Poznań University of Life Sciences, Poland. Each sample was represented by 100 pollen grains, which were analysed for two quantitative traits (Table 1) in the polar view, according to ERDTMAN (1965), and for the following qualitative traits: the shape of the pollen grains, and the type of the exine sculpture on the proximal and distal face.

The pollen grains were macerated in $10 \% \mathrm{KOH}$ (FREDERIKSEN 1978) or in glycerine and were investigated with a light microscope Olympus BX SC30 (LM) to obtain comprehensive information about the general morphology. SEM observations were conducted on the pollen grains which were dried in the air. SEM micrographs were taken with a Zeiss EVO 40 microscope at the Electron and Confocal Microscopy Laboratory, Faculty of Biology, Adam Mickiewicz University, Poznań, Poland. Prior to the observation, the prepared material was sputtered with gold by means of an SCB 050 ion sputter. The study was documented with photographs taken during the observation, mostly magnified $\times 5000$ for the shape and $\times 25000$ for the exine sculpture in SEM and $\times 40$ in LM. The micromorphological traits of the pollen grains were observed in the proximal and distal view.

The pollen terminology was adopted from ERDTMAN (1965), BAGNELl (1975), F FGRI \& IVERSEN (1975), Punt et al. (2007) and Hesse et al. (2009).

The biometric data were analysed statistically. For each pollen trait, univariate analysis of variance (ANOVA) was used to examine mean differences between the species under study. When there were significant differences observed, the ANOVAs were followed by Tukey's HSD test at $\alpha=0.05$. The statistical analyses were performed with STATISTICA 10 (StatSoft, Inc. 2011).

\section{RESULTS AND DISCUSSION}

The main morphological features of the pollen grains under investigation are summarised in Table 1. A description of the pollen grains morphology is given

Table 1. Mean values ( \pm SE) and ranges (minimum-maximum) of the morphological traits of pollen grains

\begin{tabular}{|c|c|c|c|c|}
\hline Species & $\begin{array}{l}\text { Method of } \\
\text { pollen grain } \\
\text { preparation }\end{array}$ & Length $(\mu \mathrm{m})$ & Width $(\mu \mathrm{m})$ & $\begin{array}{c}\text { Length/Width ratio } \\
\text { (shape) }\end{array}$ \\
\hline \multirow{2}{*}{ Cunninghamia lanceolata Hook. } & $\mathrm{KOH}$ & $\begin{array}{l}40.71 \pm 4.12 c \\
31.92-35.12 \\
38.32-48.26\end{array}$ & $\begin{array}{l}40.76 \pm 3.59 c \\
32.40-36.00 \\
36.16-46.00\end{array}$ & $\begin{array}{c}1.02 \pm 0.06 \mathrm{~b} \\
0.92-1.16\end{array}$ \\
\hline & glycerine & $\begin{array}{c}35.73 \pm 2.52 \mathrm{a} \\
27.57-39.74 \\
42.00-50.56\end{array}$ & $\begin{array}{c}36.50 \pm 2.90 \mathrm{ab} \\
27.10-39.11 \\
40.46-46.40(53.99)\end{array}$ & $\begin{array}{c}1.00 \pm 0.04 \mathrm{ab} \\
0.88-1.07\end{array}$ \\
\hline Cryptomeria japonica D.Don & $\mathrm{KOH}$ & $\begin{array}{c}38.33 \pm 3.23 b \\
(22.29) 25.03-29.33 \\
35.44-39.27 \\
42.28-49.22\end{array}$ & $\begin{array}{c}38.36 \pm 3.44 b \\
(21.76) 25.57-29.75 \\
32.35-39.42 \\
41.28-48.85\end{array}$ & $\begin{array}{c}0.98 \pm 0.07 \mathrm{a} \\
0.83-1.14\end{array}$ \\
\hline Sciadopitys verticillata Sieb. et Zucc. & $\mathrm{KOH}$ & $\begin{array}{c}35.45 \pm 3.28 \mathrm{a} \\
29.05-35.36 \\
36.32-42.96\end{array}$ & $\begin{array}{c}34.85 \pm 3.73 \mathrm{a} \\
27.21-36.00 \\
36.48-42.64\end{array}$ & $\begin{array}{c}1.00 \pm 0.03 \mathrm{ab} \\
0.90-1.04\end{array}$ \\
\hline ANOVA & & $\begin{array}{l}F=21.88 \\
P<0.01\end{array}$ & $\begin{array}{l}F=21.92 \\
P<0.01\end{array}$ & $\begin{array}{l}F=3.95 \\
P=0.01\end{array}$ \\
\hline
\end{tabular}

One way ANOVAs were performed separately for each features to determine the differences among taxa studied. Same letters indicate a lack of statistically significant differences between analyzed taxa according to Tukey's a posteriori test $(\mathrm{P}<0.05)$. 

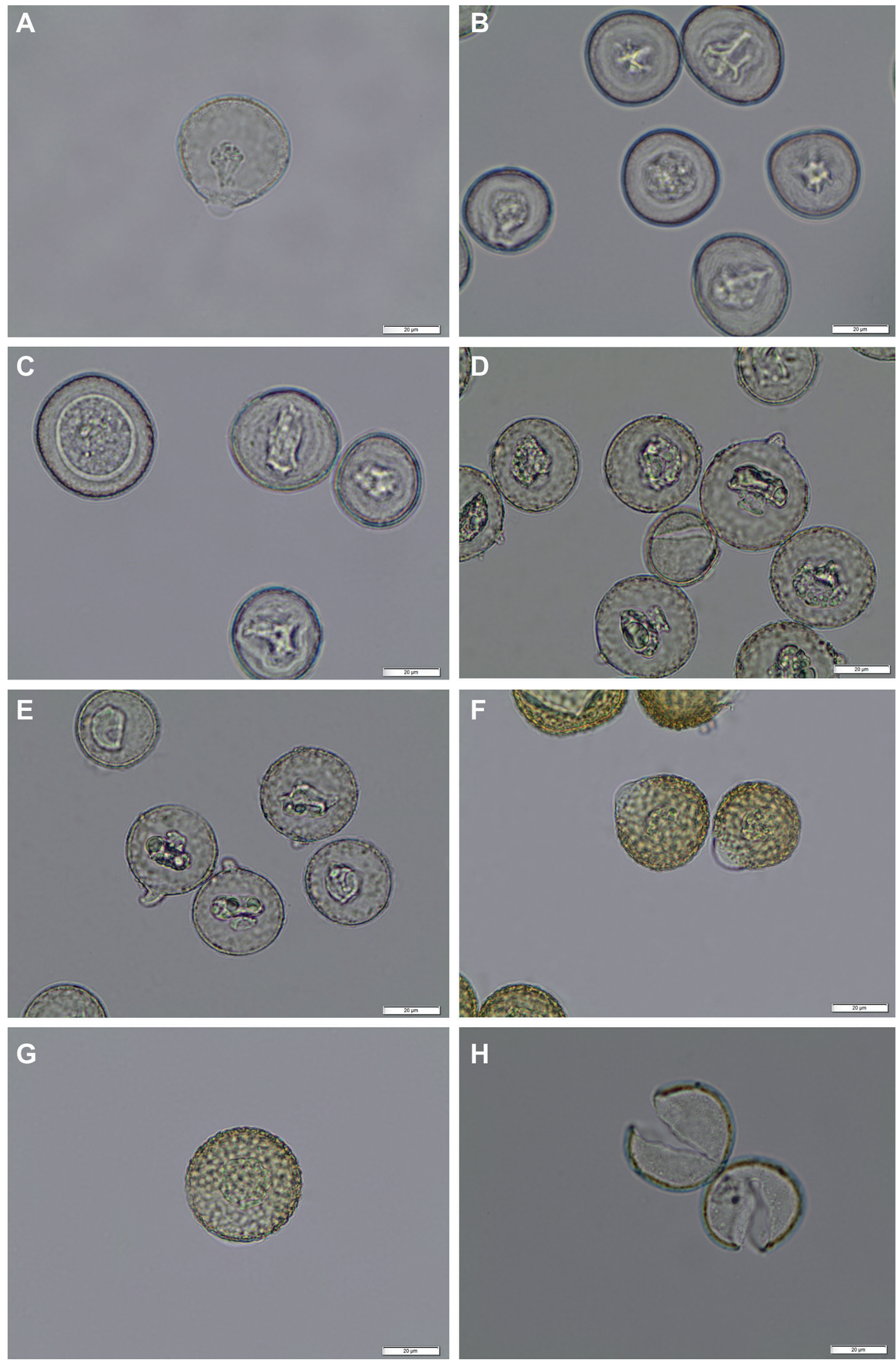

H

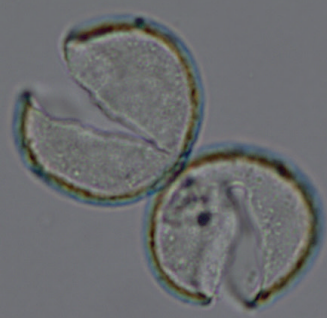

Fig. 1. Light microscope micrographs (LM) of pollen grains in the equatorial and polar view: A, B - Cunninghamia lanceolata; C, D, E - Cryptomeria japonica; F, G - Sciadopitys verticillata; H - Cunninghamia lanceolata, split pollen; pa - papilla 
below and illustrated with selected SEM and LM photographs (Figs 1-4).

\section{CUNNINGHAMIA LANCEOLATA (TABLE 1, FIGS 1A, B, H, 2)}

The pollen grains were single. The size of the pollen grains depended on the method of specimen preparation. In the polar view they were on average 35.73 or $40.71 \mu \mathrm{m}$ long and 36.50 or $40.76 \mu \mathrm{m}$ wide. The pollen grains macerated in $\mathrm{KOH}$ were about $5 \mu \mathrm{m}$ bigger than those fixed in glycerine (Table 1). The pollen size varied considerably. There were small grains, which diameters were less than $30 \mu \mathrm{m}$, and large grains, which diameters ranged up to more than $50 \mu \mathrm{m}$ (Table 1). The papilla in the equatorial view was $4-5 \mu \mathrm{m}$ long and the basal width was $10 \mu \mathrm{m}$. The shape of the pollen grains fixed in $\mathrm{KOH}$ ranged from oblate-spheroidal to subprolate, whereas the shape of the pollen grains fixed in glycerine ranged from oblate-spheroidal to prolate-spheroidal (Table 1, Fig. 1A, B).

In the proximal view the pollen grains were convex (Fig. 2A, B). The exine in the proximal view was verrucate-granulate with microechinate orbicules (Fig. $2 \mathrm{~A}-\mathrm{C})$. The shape of the verrucae was rounded, with polygonal cover with microgranules. The tectum was sparsely perforate with small holes and puncta (Fig. 2C, F), similar as in Pinus mugo, P. sylvestris, $P$. $\times$ rhaetica (Вукошsка \& Kцimко 2015), P. uliginosa and P. uncinata (Кцімко \& Bукоwsка 2015). In the proximal view the verrucae were irregular in size and height and the pattern was noticeable on the majority of grains. In SEM the distal face on the germinal apparatus was concave, rounded or ovate, bordered by a rim from the proximal hemisphere and it differed in sculpture
(Fig. 2D, E). In great magnification the area of the leptoma was microgranulate and there were echinate orbicules found (Fig. 2F). The echinate orbicules were similar as in the proximal view. We observed the leptoma with a short papilla on the distal face of the pollen grains in SEM (Fig. 2D-F), in LM in the equatorial view (Fig. 1A) and in the polar view (Fig. 1B).

The pollen size observed in our study was partly similar to other authors' observations. Surova \& Kvavadze (1988) researched pollen grains from the Botanical Garden in Georgia. They observed that the size of C. lanceolata pollen grains was $28.0-39.0 \mu \mathrm{m}$ (we observed larger grains, too). The leptoma was large and occupied nearly the entire distal surface. It was pore-shaped and 1.5-2.0 $\mu \mathrm{m}$ in size. Part of the distal surface was smooth, the granules were very small and sparsely distributed. In the study by KURMANN (1990) pollen grains were larger and their diameters ranged from 31.0 to $53.0 \mu \mathrm{m}$. In our study the diameter of the largest grains slightly exceeded $48 \mu \mathrm{m}$. We also observed that in the specimens macerated in $\mathrm{KOH} 52.06 \%$ of the pollen grains were deformed (broken) (Fig. 1H).

The presence of a papilla on C. lanceolata pollen grains is disputable. According to ERDTMAn (1965), the pollen had a pore-like aperture. UENo (1951) reported that the papilla was absent in this species. Similarly to our study, Wodehouse (1935), Ho \& SZiKLAi (1973) and Grímsson \& Zetter (2011) observed the presence of a papilla.

\section{CRYPTOMERIA JAPONICA (TABLE 1, FIGS 1C-E, 3)}

The pollen grains were single. In the polar view they were on average $38.33 \mu \mathrm{m}$ long and $38.36 \mu \mathrm{m}$ wide.
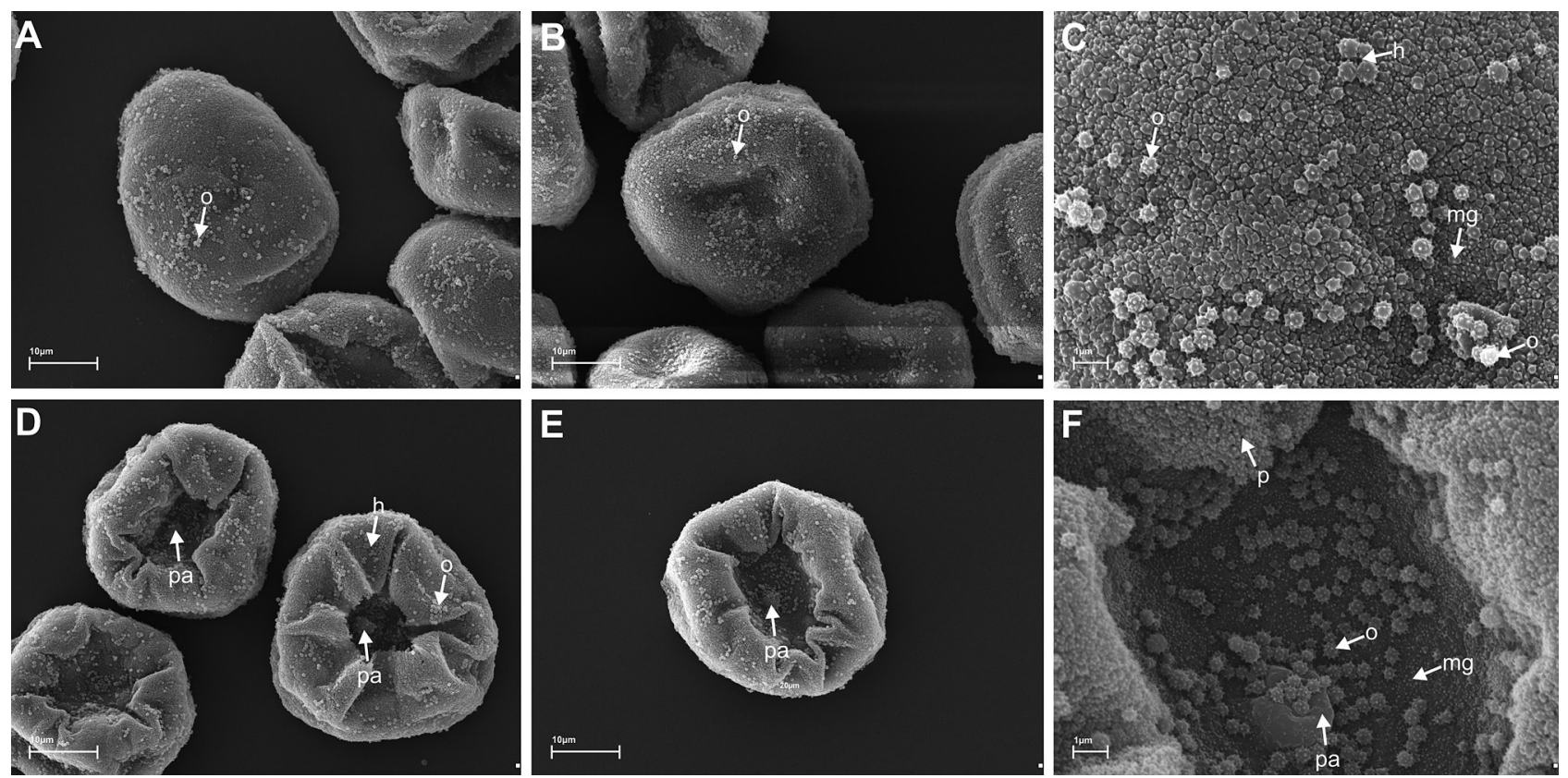

Fig. 2. Scanning electron micrographs (SEM) of Cunninghamia lanceolata pollen grains; $h$ - holes, $m g$ - micrograna, $o$ - orbicule, $p$ - puncta, $p a-$ papilla 
The pollen size varied considerably. The length of individual C. japonica pollen grains ranged from 22.29 to $49.22 \mu \mathrm{m}$, and the width ranged from 21.76 to $48.85 \mu \mathrm{m}$. As far as the size of the pollen grains, we can distinguish three groups (Table 1). It was very easy to notice the papilla in C. japonica (Figs 1D, E, $3 \mathrm{C}-\mathrm{E})$. Its length in the equatorial view ranged from 2.34 to $5.55(-6.27) \mu \mathrm{m}$, and the basal width ranged from 4.62 to $8.64 \mu \mathrm{m}$. The size of the pollen grains and papilla were not positively correlated. The shape of the pollen grains in the polar view ranged from oblate-spheroidal to subprolate (Table 1, Fig. 1D, E).

The pollen grains were convex in the proximal view (Fig. 3A). The exine was verrucate-granulate, covered with echinate orbicules (Fig. 3A, B). The tectum was sparsely perforate, with small holes (Fig. $3 \mathrm{~B})$. In the proximal view the verrucae were irregular in size and height and the pattern was noticeable on the majority of grains. In SEM the distal face was concave and it had a straight papilla (Figs. 3C-F). In LM straight or curved papillae were observed. The surface of the papilla was microgranulate with echinate orbicules (Fig. 3D-F). In the distal view in great magnification the exine was microgranulate and there were echinate orbicules found (Fig. 3F). The echinate orbicules were similar as in the proximal view. In the specimens macerated in $\mathrm{KOH}$ and glycerine only individual grains were broken.

In our study the $C$. japonica pollen grains were larger than in the reference publications. According to WANG et al. (2012), the diameter of $C$. japonica pollen grains was about $30 \mu \mathrm{m}$. Uehara \& SaHASHI (2000) reported that $C$. japonica pollen was generally spherical and 25 $-35 \mu \mathrm{m}$ in diameter. The surface of the body zone was granular. There were small spherical orbicules. The pa- pilla was in the centre of the germinal zone and the tip of papilla was slightly curved. In our study the tip of the papilla was straight, blunt or slightly curved. GRímsson \& ZetTer (2011) reported that C. japonica fossil pollen grains were $25-33 \mu \mathrm{m}$ wide in LM and 24-27 $\mu \mathrm{m}$ wide in SEM, whereas the polar axis was $20-26 \mu \mathrm{m}$ long in LM (the diameter of our pollen grains ranged up to about $45 \mu \mathrm{m}$ ). The sculpturing was scabrate in LM, microverrucate in SEM. The surface of the leptoma was granulate, with large irregularly distributed microechinate orbicules (SEM). Ho \& SzIKLAI (1973) described dry pollen of cryptomeria as cherry-like. The distal face of the pollen was concave, with a slightly bent papilla. The sculpture pattern was microverrucate and the granules of the sculptural element were ornamented, spinulose. The papilla was microscabrate rather than microverrucate.

\section{SCIADOPITYS VERTICILLATA (TABLE 1, FIGS 1F, G, 4)}

The pollen grains were single. On average they were $35.45 \mu \mathrm{m}$ long and $34.85 \mu \mathrm{m}$ wide (measured in the polar view). The pollen size varied considerably. Two pollen groups were distinguished - small grains sized about $29-35 \times 27-36 \mu \mathrm{m}$ and big grains, which were about $36-43 \mu \mathrm{m}$ long and $36-43 \mu \mathrm{m}$ wide. The papilla in the equatorial view was $4-5 \mu \mathrm{m}$ long, and the basal width was $17 \mu \mathrm{m}$. The shape of the pollen grains in the polar view ranged from oblate-spheroidal to prolate-spheroidal (Table 1, Fig. 1F, G).

The pollen grains were convex in the proximal view (Fig. 4A, B). The exine was verrucate (Fig. $4 \mathrm{~A}-\mathrm{C})$. All verrucae were with microgranules, microechinate, irregularly dispersed. No echinate orbicules
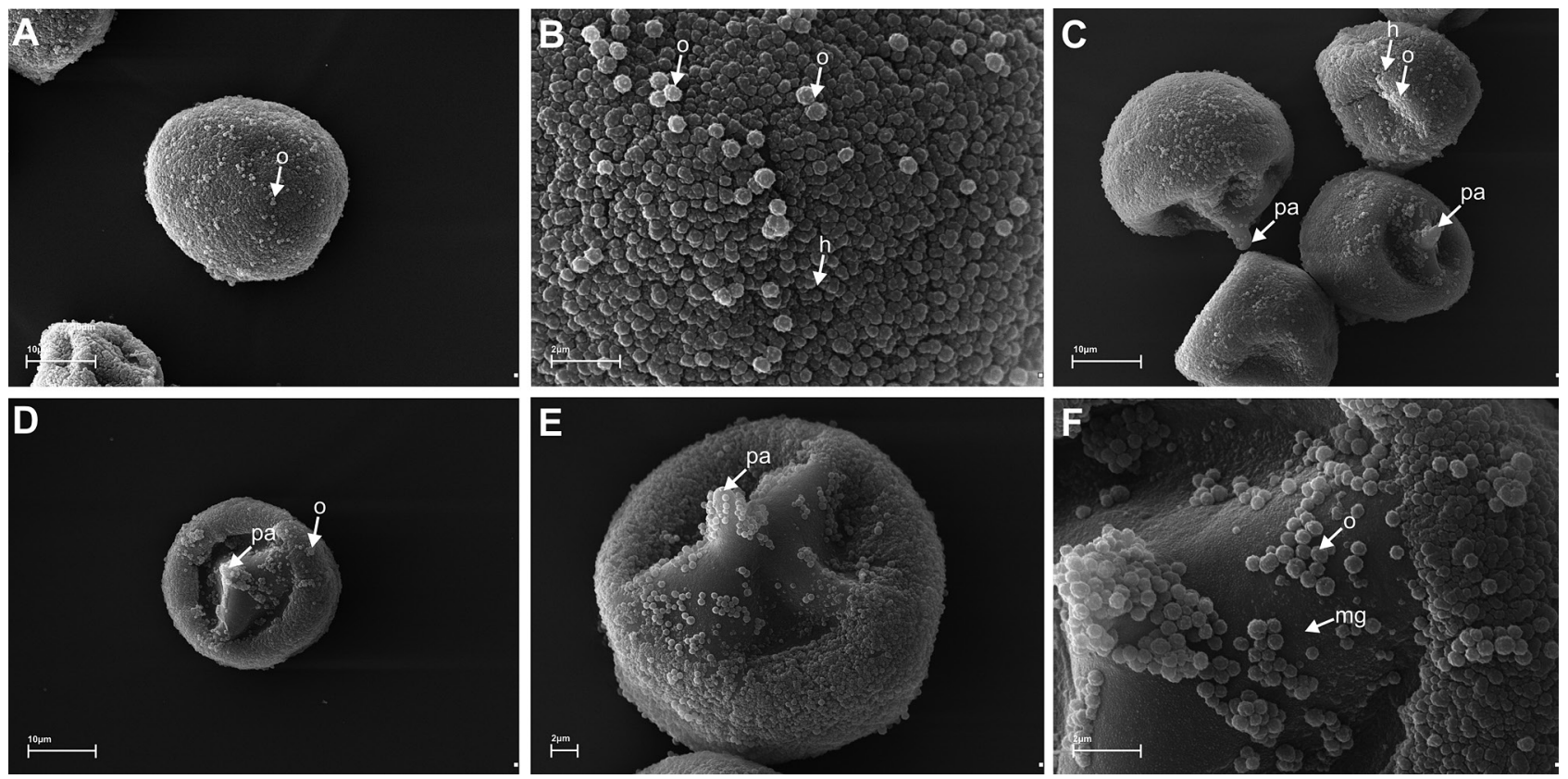

Fig. 3. Scanning electron micrographs (SEM) of Cryptomeria japonica pollen grains; $h$ - holes, $m g$ - micrograna, $o$ - orbicule, $p$ - puncta, $p a-$ papilla 
were observed in the proximal view. The exine was clearly perforate with puncta and small holes (Fig. $4 \mathrm{C})$. The size of the verrucae in the proximal view was irregular in size and the pattern was noticeable on the majority of grains. The distal face of the pollen grains was concave in SEM (Fig. 4D, E, G). In great magnification the exine on the distal face was microgranulate (Fig. 4F, H) or almost smooth and there were echinate orbicules found (Fig. 4I). The orbicules on the germinal zone of some pollen grains were diversified in size and shape (Fig. 4F, I) or almost invisible (Fig. 4H). There were no orbicules in the proximal view in SEM. We observed the papilla in the pollen grains in the equatorial view in SEM (Fig. 4B) and in LM (Fig. 1F). We observed that in the specimens macerated in $\mathrm{KOH} 53.85 \%$ of the pollen grains were deformed (broken).

According to Grímsson \& ZetTer (2011), S. verticillata pollen was comparable in size or slightly larger than the largest pollen of the Cupressaceae, Cephalotaxaceae and Taxaceae families. Our research findings partly confirm these observations, as well as the observations made by Ueno (1951), who noted that the diameter of $S$. verticillata pollen grains was 33-38 $\mu \mathrm{m}$ (we observed larger grains, too). Kvavadze
(1986) and Surova \& Kvavadze (1988) reported that the diameter of pollen grains (subjected to acetolysis) was $36-71 \mu \mathrm{m}$ (in our study the diameter of the largest grains did not exceed $45 \mu \mathrm{m}$ ). The researchers distinguished the following three forms of grains, depending on their shape and size of orbicules on the distal side: small orbicules of identical size, large orbicules of different sizes and adjacent or merging orbicules. Our research also showed considerable diversification in the size of orbicules in the germinal zone (Fig. 4F, H, I).

XI (1986) described the pollen surface ornamentation as rugulate and this tectum can be distinguished from the pollen grains of other genera. Ho \& SZIKLAI (1973) observed gemma on the proximal surface. We did not make this observation in our study. МАс́ко (1957) described S. verticillata fossil pollen grains from lower Miocene in Poland. The average diameter of the pollen grains was $33-55 \mu \mathrm{m}$ or $46-55$ $\mu \mathrm{m}$, the pollen exine was densely wrinkled superficially. The author saw no differences between the features of fossil and recent forms. GRímsson \& ZETTER (2011) reported that the fossil pollen grains from Austria were 38-45 $\mu \mathrm{m}$ wide in LM, 35-40 $\mu \mathrm{m}$ wide in SEM, and the polar axis was 31-34 $\mu \mathrm{m}$ long in LM.
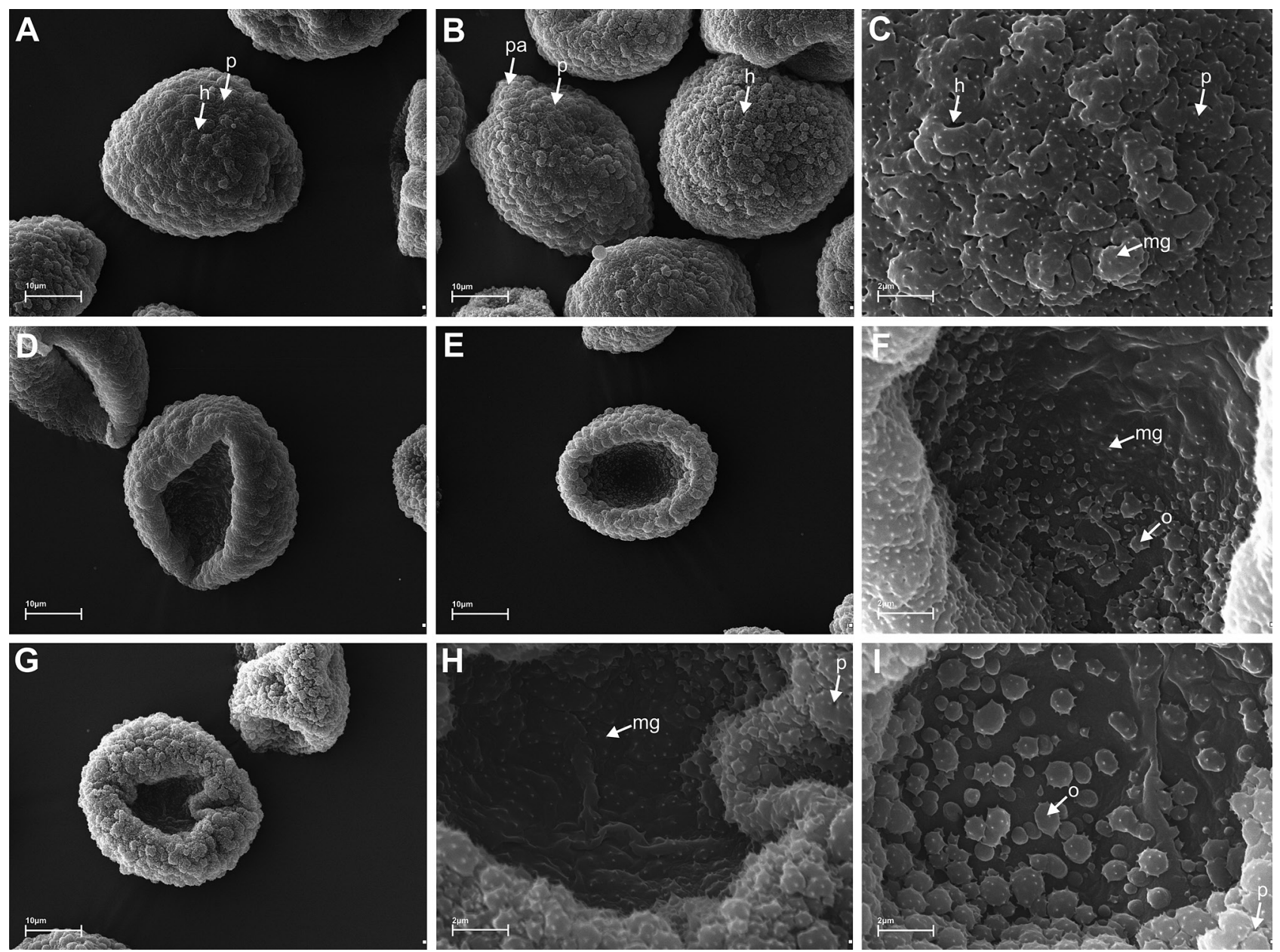

Fig. 4. Scanning electron micrograph (SEM) of Sciadopitys verticillata pollen grains; $h$ - holes, $m g$ - micrograna, $o$ - orbicule, $p$ - puncta, $p a-$ papilla 
The sculpturing was verrucate in LM, verrucate with microechinate suprasculpture in SEM, the verrucae were with perforation. Our research confirmed these observations.

KvAVADZE (1986) suggested that the polymorphism and high percentage of pollen deformation observed in S. verticillata growing in a culture were caused by unfavourable conditions for its normal development. We think that it was also caused by the preparation of specimens. When dried pollen grains were used in SEM, very few of them were deformed (in contrast to the grains macerated in $\mathrm{KOH}$ ). There were similar results in LM (liquid preparation - glycerine).

\section{CONCLUSIONS}

In conclusion, our study of the morphology of Cunninghamia lanceolata, Cryptomeria japonica and Sciadopitys verticillata pollen grains provided some important new data concerning the size, shape and ornamentation on the proximal surface and distal face. The biometric measurements of the two quantitative traits in the polar view were of little help for the identification. In general, the pollen grains were medium-sized, according to ERDTMAN's classification (ERDTMAN 1965). The general shape of the pollen grains in the polar view (length/width ratio) was oblate-spheroidal, spheroidal and prolate-spheroidal. The traits of the exine surface in the proximal view were less variable and they were a good criterion of identification of the species under study. C. lanceolata and C. japonica differed in the shape and size of the papillae and in the shape of echinate orbicules on the proximal surface. Our study showed that several traits of the pollen morphology could be of taxonomical value. Thus, this detailed analysis greatly increased our knowledge of individual species.

\section{ACKNOWLEDGEMENTS}

We would like to thank Ilona Wysakowska for her technical assistance and Wojciech Klimko for his assistance with computer data records. The authors would like to thank two anonymous reviewers for their suggestions and comments made on an earlier version of the manuscript. This study was supported by the Department of Botany and Department of Dendrology and Nursery, Poznań University of Life Sciences.

\section{REFERENCES}

BAGNell JR. C.R. (1975): Species distinction among pollen grains of Abies, Picea, and Pinus in the Rocky Mountain Area (a scanning electron microscope study). Review of Paleobotany and Palynology 19: 203-220.
Вүкошsка J., Kцiмко M. (2015): The pollen morphology of Pinus mugo Turra $\times$ Pinus sylvestris L. hybrids and parental species in an experimental culture. Acta Biologica Cracoviensia Botanica 57(1): 149-160. DOI: 10.1515/abcsb-2015-0009.

Christenhusz M.J.M., Reveal J.L., Farjon A., Gardner M.F., Mill R.R., Chase M.W. (2011): A new classification and linear sequence of extant gymnosperms. Phytotaxa 19: 55-70.

ERdTMAn G. (1965): Pollen and spore morphology. Plant Taxonomy. Gymnospermae, Pteridophyta, Bryophyta. Almqvist and Wiksell, Stockholm-New York.

FÆGRI K., IVERSEN J. (1975): Textbook of pollen analysis. Munksgaard, Copenhagen.

Ferguson D.K., Pingen M., Zetter R., Hofmann C.C. (1998): Advances in our knowledge of the Miocene plant assemblage from Kreuzau, Germany. Review of Paleobotany and Palynology 101: 147-177 .

Frederiksen N.O. (1978): Preservation of cycad and Ginkgo pollen. Review of Paleobotany and Palynology 25: 163-179.

Grímsson F., Zetter R. (2011): Combined LM and SEM study of the Middle Miocene (Sarmation) palynoflora from Lavanttal Basin, Austria: Part 2. Pinophyta (Cupressaceae, Pinaceae and Sciadopityaceae). Grana 50: 262-310.

Hansen B.C.S., Grimm E.C., Watts W.A. (2001): Palynology of the Peace Creek site, Polk County, Florida. Geological Society of America Bulletin 113(6): 682-692.

HAYATA B. (1931): The Sciadopityaceae represented by Sciadopitys verticillata Sieb. et Zucc., an endemic species of Japan. Botanical Magazine (Tokyo) 45: 567-569.

Hesse M., Halbritter H., Zetter R., Weber M., Buchner R., Frosch-Radivo A., Ulrich S. (2009): Pollen terminology. An illustrated handbook. Springer, Wien.

Ho R.H., SzikLai O. (1973): Fine structure of the pollen surface of some Taxodiaceae and Cupressaceae species. Review of Paleobotany and Palynology 15: 17-26.

Jia G., Chen Z-K., Shen H. (1998): Pollen ontogeny and its wall formation in Cunninghamia lanceolata. Grana 37: 343-351.

KLIMKO M., BYкоwSKA J. (2015): Pollen morphology of Pinus uliginosa Neum. and Pinus uncinata Ramond ex DC in an experimental culture. Steciana 19(3): 153-161.

KuRMANN M.H. (1990): Exine formation in Cunninghamia lanceolata (Taxodiaceae). Review of Paleobotany and Palynology 64: 175-179.

KuRMANN M.H. (1992): Exine stratification in extant gymnosperms: a review of published transmission electron micrographs. Kew Bulletin 47: 25-39. 
Kvavadze E.V. (1986): Electron studies of the surface shell sculpture of the pollen grains of Sciadopitys verticillata Sieb. et Zucc. Bulletin of the Academy of Sciences of the Georgian SSR 121(2): 421-424 (in Russian).

Larsson L.M., Vajda V., DybKjaer K. (2010): Vegetation and climate in the latest Oligocene-earliest Miocene in Jylland, Denmark. Review of Paleobotany and Palynology 159: 166-176.

МАс́ко S. (1957): Lower Miocene pollen flora from the valley of Kłodnica near Gliwice (Upper Silesia). Prace Wrocławskiego Towarzystwa Naukowego, ser. B, 88: 46-47.

PAGE C.N. (1990): Taxodiaceae. In: K.U. Kramer, P.S. Green (eds). The families and genera of vascular plants. Vol. 1. Pteridophytes and Gymnosperms. Springer, Berlin: 353-361.

Punt W., Hoen P.P., Blackmore S., Nilsson S., Thomas A. (2007): Glossary of pollen and spore terminology. Review of Paleobotany and Palynology 143: $1-81$.

Seneta W. (1981): Drzewa i krzewy iglaste. PWN, Warszawa.

Seneta W., Dolatowski J. (2000): Dendrologia. Wyd. Nauk. PWN, Warszawa.

Stuchlik L., ZiembińsKa-Tworzydeo M., Kohlman-Adamska A., Grabowska I., WaŻyŃsKa H., SAdOWSKA A. (2002): Atlas of pollen and spores from the Polish Neogene. Vol. 2. Gymnosperms. W. Szafer Institute of Botany, Polish Academy of Sciences, Kraków.

Surova T.D., Kvavadze E.V. (1988): Sporoderm ultrastructure in some gymnosperms (Metasequoia, Cunninghamia, Sciadopitys). Botanicheskij Zhurnal (Leningrad) 73(1): 34-44 (in Russian).

Schulz Ch., Stützel T. (2007): Evolution of taxodiaceous Cupressaceae (Coniferopsida). Organisms, Diversity \& Evolution 7: 124-135.

Tanaka A., Minoguchi K., Pawankar R., Adachi M. (2012): Asthma in patients with Japanese cedar pollinosis. World Allergy Organization Journal 5: 218-222.

Troć M., Sadowska A. (2006): Wiek utworów formacji poznańskiej rejonu Poznania. Przegląd Geologiczny (54)7: 588-593.

Uehara K., Sahashi N. (2000): Pollen wall development in Cryptomeria japonica (Taxodiaceae). Grana 39: 267-274.

Uehara K., Saiki K. (2011): Pollen wall development in Sciadopitys verticillata (Sciadopityaceae). Plant
Systematic and Evolution 294: 177-183. DOI 10.1007/s00606-011-0449-8.

Ueno J. (1951): Morphology of pollen of Metasequoia, Sciadopitys and Taiwania. Journal of the Institute of Polytechnics, Osaka City University (D) 2: 22-26.

Ueno J. (1960): Studies on pollen grains of gymnospermae. Concluding remarks to the relationships between Coniferae. Journal of the Institute of Polytechnics, Osaka City University (D) 11: 109-136.

Wang Q., Gong X., Suzuki M., Lu S., Sekiguchi K., Nakajina D., Miwa M. (2013): Size-segregated allergenic particles released from airborne Cryptomeria japonica pollen grains during the yellow sand events within the pollen scattering seasons. Asian Journal of Atmospheric Environment 7-4: 191-198. DOI: http://dx.doi.org/10.5572/ ajae.2013.7.4.191

Wang Q., Nakamura S., Lu S., Xiu G., Nakajima D., SuzuKi M., SAкамото K., Miwa M. (2012): Release behavior of small sized daughter allergens from Cryptomeria japonica pollen grains during urban rainfall event. Aerobiologia 28(1): 71-81. DOI 10.1007/s10453-011-9212-4.

Wodehouse R.P. (1935): Pollen grains. McGraw-Hill, New York.

XI Y.-Z. (1986): Studies on pollen morphology of Taxaceae. Bulletin of Botanical Research 6(3): 127-144.

XI Y.-Z., Wang F.H. (1989): Pollen exine ultrastructure of extant Chinese gymnosperms. Cathaya 1: 119-142.

Yamada Y., Nagashima K., Kabasawa M. (1980): The ultrastructure of pollen wall and tapetal membranes in Cryptomeria japonica D. Don. Japan Journal Palynological 25: 21-31.

Yonekura S., Okamoto Y., Horiguchi S., OkUbo K., Gotoh M., Konno A., Okuda M. (2012): Early intervention for Japanese cedar and cypress pollinosis. Clinical \& Experimental Allergy Reviews 12: 10-16.

Zetter R. (1998): Palynological investigations from the early Miocene lignite opencast mine Oberdorf (N Voitsberg, Styria, Austria). Jahrbuch der Geologischen Bundesanstalt 140: 461-468.

For citation: Byкоwska J., Kцimko M. (2016): Pollen morphology in selected Cupressaceae Gray. and Sciadopityaceae Luerss. species in an experimental culture. Steciana 20(1): 7-14. doi: 10.12657/ steciana.020.002 